THE COST OF TRANSPORTATION'S OIL DEPENDENCE

David L. Greene

Center for Transportation Analysis

May 1995

Prepared by the

Oak Ridge National Laboratory

Oak Ridge, Tennessee 37831-6207

managed by

LOCKHEED MARTIN ENERGY SYSTEMS, INC.

for the

U. S. DEPARTMENT OF ENERGY

under contract DE-AC05-84OR21400

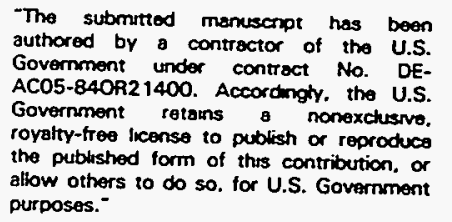

purposes." 


\section{DISCLAIMER}

Portions of this document may be illegible in electronic image products. Images are produced from the best available original document. 


\title{
The Cost of Transportation's Oil Dependence
}

\author{
David L. Greene
}

Oak Ridge National Laboratory, Oak Ridge, Tennessee 37831-6207, USA

The societal costs of oil dependence do not fit neatly into the definition of a market externality. Though oil dependence costs have some of the features of external costs. result from what most would agree is a market failure. and almost certainly demand some form of public policy action. the paradigm of the public good externality fails to capture the essence of the problem. The essence of the oil problem is as follows: 1) the geographical concentration of oil resources in a relatively few countries creates the potential for significant market disruptions. most especially the exercise of monopoly power by a cartel; 2) the inelasticity of oil supply and demand. especially in the short-run. confers enormous monopoly power even on a cartel holding less than half of the world market: 3 ) developed and developing nations. especially their transport sectors, consume enormous quantities of oil making them vulnerable to oil price shocks and price increases.

One reason the oil dependence problem is complex is that it has political and military, as well as economic dimensions (e.g., Hall. 1992; Greene and Leiby, 1993). This paper will focus on the economic costs for two reasons. First, my own research on the United States suggests that the economic costs are one to two orders of magnitude larger than the monetary components of the political and military costs combined. Second. the economic costs appear to be more easily rigorously defined and measured. Military and political costs are often not readily monetizable. and are generally difficult, if not impossible, to definitively attribute to the use of or dependence on oil. It is not at all my view that such costs are not important because they are. The point is simply to be clear about which costs of oil dependence are treated here and which are not.

Transportation is critical to the world's oil dependence problem because of the large share of world oil it consumes and because of its intense dependence on oil. In the United States, transportation consumes two thirds of all petroleum products but. more importantly, requires $80 \%$ of the light products that drive the oil market. In the OECD, transportation oil use is nearly $60 \%$ of total and is $90 \%$ petroleum. Moreover, oil accounts for nearly all of the energy use in transportation. In the U.S. oil is $97 \%$ of transportation energy use, exactly the same as in 1972. despite the oil market upheavals of the past twenty years. If one neglects pipelines. oil is over $99 \%$ of U.S. transportation energy use. Doubling and tripling (albeit temporarily) of worid oil prices have been unable to create significant transportation markets for non-petroleum fuels.

\section{The Costs of Oil Dependence}

The problem of oil dependence is not that the world is imminently "running out of oil". Furthermore. it is only partly a question of how much oil a nation imports. Oil dependence is a problem of the use of monopoly power in world oil markets by a cartel of nations that hold the majority of the world's known and estimated oil resources. The problem is economically significant consumption of a cartelized resource for which both supply and demand are inelastic. The inelasticity of supply and demand confer enormous market

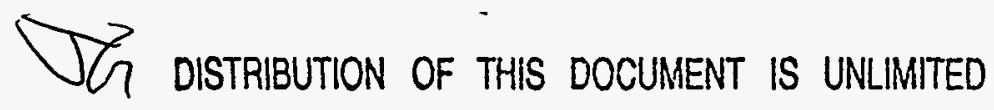


power on the oil cartel. depending on its share of the world oil market. The problem is complicated by the fact that short-run elasticities are far smaller that long-run elasticities. and therefore price shocks are likely.

The exercise of monopoly power clearly constitutes a market failure. in the sense that it is a deviation from a competitive market. It is also clearly not a market failure that can be corrected by individual consumers or producers acting in their private interests. The market failure of monopoly almost certainly requires collective action to correct. But the costs of oil dependence do not conform neatly to the definition of a market externality. Although the consumption of an additional barrel of oil generates some additional costs which can be construed as marginal social costs. it is not obvious that these costs fully comprise the costs of oil dependence. Nor would a Pigouvian tax based on such marginal social costs necessarily lead to an economically efficient solution (although it might be an improvement). In short. characterizing oil dependence costs as externalities fails to adequately characterize them and does not point towards their solution.

\section{The Oil Problem}

By accident of geological history. the majority of the world's oil reserves are concentrated within the borders of a relatively few nations. The member states of OPEC hold the lion's share of world oil resources by any measure. The Oil and Gas Journal estimates that OPEC countries contained $77 \%$ of the world's 996 billion barrels of proved reserves of crude oil (Figure 2.1). World Oil, which puts reserves in the former USSR 130 billion barrels higher has OPEC's share at $66 \%$ of 1.092 billion barrels (U. S. DOE/EIA, 1994c, table 36). Although there is no standard international definition of proved reserves. these estimates generally reflect crude oil resources that have been discovered and are economically and technically feasible to produce at prices similar to those prevailing in recent history. Certainly there are more petroleum resources in the world than reflected in the proved reserves estimates.

Best estimates of the world's ultimately recoverable petroleum resources, discovered and yet to be discovered, however, also show OPEC dominance. The U. S. Geological Survey's worid petroleum assessment puts "World Ultimate Resources" of oil at 2.3 trillion barrels. of which about 0.7 trillion barrels have already been produced. This leaves 1.6 trillion to be recovered. $60 \%$ more than reflected in proven reserves (Masters. Attanasi. and Root. 1994). Of the estimated remaining ultimate resources, OPEC countries hold just over $55 \%$ and the U.S. just under $6 \%$. At present. OPEC nations are producing at a rate of about $1 \%$ of their ultimate resources per year. The rest of the world. however. is drawing down their resources at an average rate of $1.9 \%$ per year. The trend is clear: an increasing OPEC share of world oil resources and of worid oil production.

Although world petroleum resources are uitimately finite, the world is not imminently "running out of oil" (Gordon. 1994). At 1992 consumption rates. the 1.6 trillion barreis of ultimate resources would last 65 years. There are. in addition. vast unconventional oil resources in the form of extra heavy oils. tar sands, and oil shale. Extra heavy oil deposits in the Orinoco province of Venezuela and tar sands in Western Canada together are judged to be equivalent to 0.6 trillion barrels of crude oil. roughly the proved reserves of the entire Middle East. These two deposits alone would add another 25 years at current consumption rates.

If the world is not "running out of oil". then the price shocks and market gyrations of the past two decades must be due to something else. and that something eise is the use of monopoly power by the OPEC cartel. Basic economic theory applied to the history of world oil prices proves to be very enlightening. Economic theory demonstrates that in a static market a monopolist maximizes profits by charging a price. $P$, that exceeds the cost of production. $C$. (including the normal return to capital). 
Figure 2.1

\section{World Oil Resources Estimates, 1993 Proved Reserves v. Ultimate Resources}
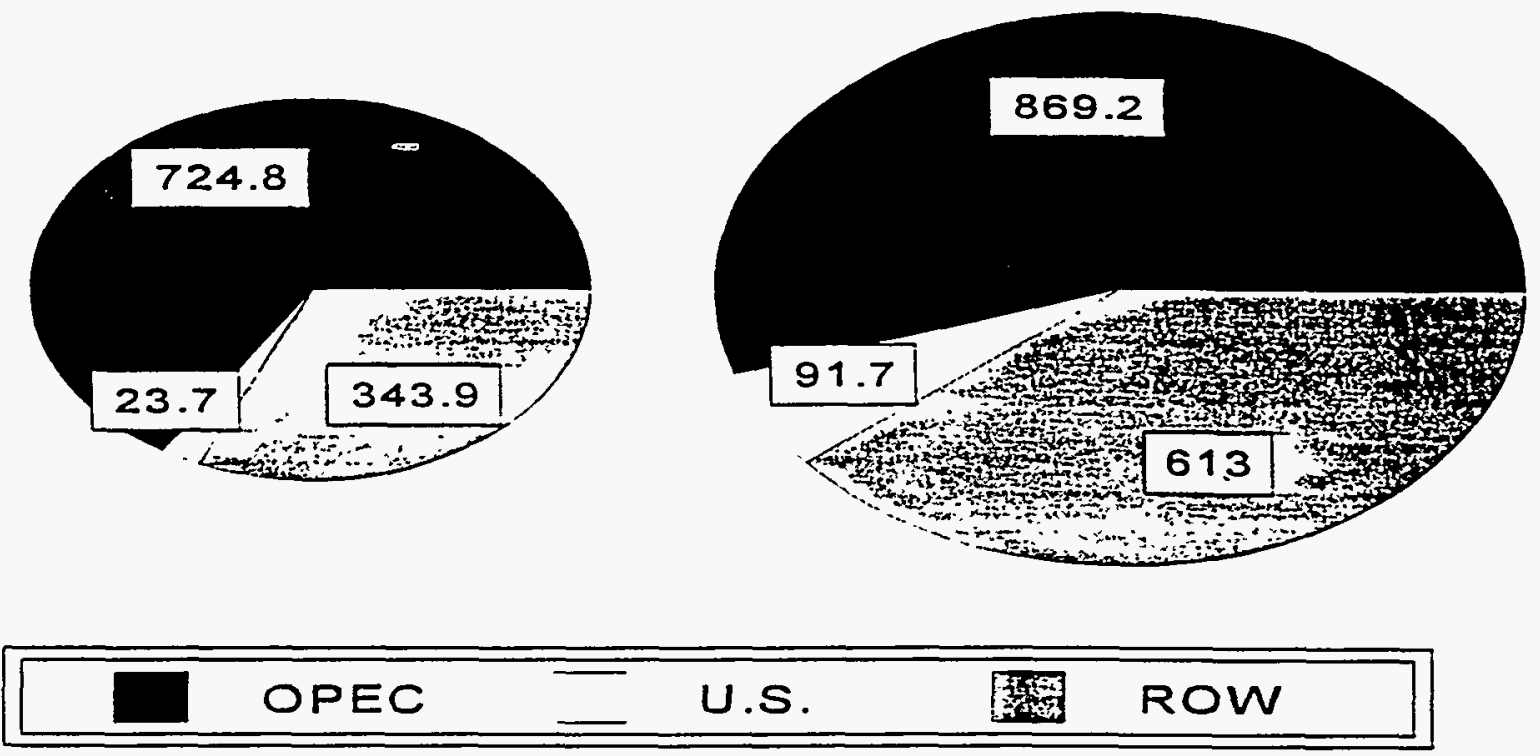

Source: U. S. DOE/ElA. 1994 c. Table 36; Masters. Attanasi, and Root. 1994, Table 1

$$
\frac{P}{C}=\frac{1}{\left(1+\frac{1}{\beta(P)}\right)}
$$

In reality, it is very rare for a monopoly to control $100 \%$ of a market. For a monopoly controlling a large share, $0<\mathrm{s}<1$, of a market. things are a bit more complicated. The profit maximizing price depends on the price elasticity of demand. but it also depends on the monopolist's market share. as well as on the ability of competitors to respond to a reduction in supply by the monopolist (Greene. 1991). In equation (2) which defines the profit maximizing price for such a partial monopolist. $\mu$ is defined as the change in quantity supplied by competitors for a one unit increase in supply by the monopolist. Here, it is the negative of the number of barrels supplied by the ROW for a one barrel-per-day reduction in supply by OPEC.

$$
\frac{P}{C}=\frac{1}{1+\left(\frac{1}{\beta(P)} s(\mu(P)+1)\right)}
$$

This equation has several important features. Like equation ( 1 ), the larger $\beta$ is. the smaller the ratio P/C. Also. the smaller the monopolistic share. s. the smaller $\mathrm{P} / \mathrm{C}$. This is very important for understanding the 
recent history of world oil prices. As OPEC loses market share in defending higher prices. its profit maximizing price must fall. Put another way, its monopoly power. defined as the ability to raise prices without loss of profit. declines. Finally, the more responsive the ROW oil supply, $\mu$, the smaller P/C. If the ROW can meet OPEC's supply reductions barrel for barrel. at the same price, the cartel has no monopoly influence over prices. Supply responsiveness is a direct function of the price elasticity of supply, as one would expect (Greene. 1991).

The large difference between short-run and long-run oil market price elasticities implies that the cartel can force prices much higher in the short-run than can be maintained in the long-run (Greene, 1991; MacFadyen, 1993). In the short-run. P/C ratios may exceed 5. In the long-run they are probably less than 2. Thus, small supply shortfalls on the order of $10 \%$ or less can create enormous price shocks in the short-run. but such price levels cannot be maintained in the long-run. To maintain high prices. the cartel must sacrifice market share. But as it gives up market share it gives up the ability to maintain high prices. There is no way out. Maintaining prices at short-run profit-maximizing levels requires loss of market share which eventually requires lowering prices. Retaining market share requires lowering prices. This pattern is clearly evident in the history of oil prices and OPEC market share of the 1970s and 1980s. In Figure 2.2 oil price is plotted against the market share of the OPEC core nations: Saudi Arabia, Kuwait. Iraq, Iran. the United Arab Emirates. and Lybia. Years are identified by their last two digits. Curves representing the long-run and short-run $\mathrm{P} / \mathrm{C}$ ratios as functions of the core OPEC nations share of the world market have also been plotted. The curves have been drawn using consensus elasticity estimates based on the energy economics literature.' The 1972 world oil price is assumed to be the competitive price (c) for all years.

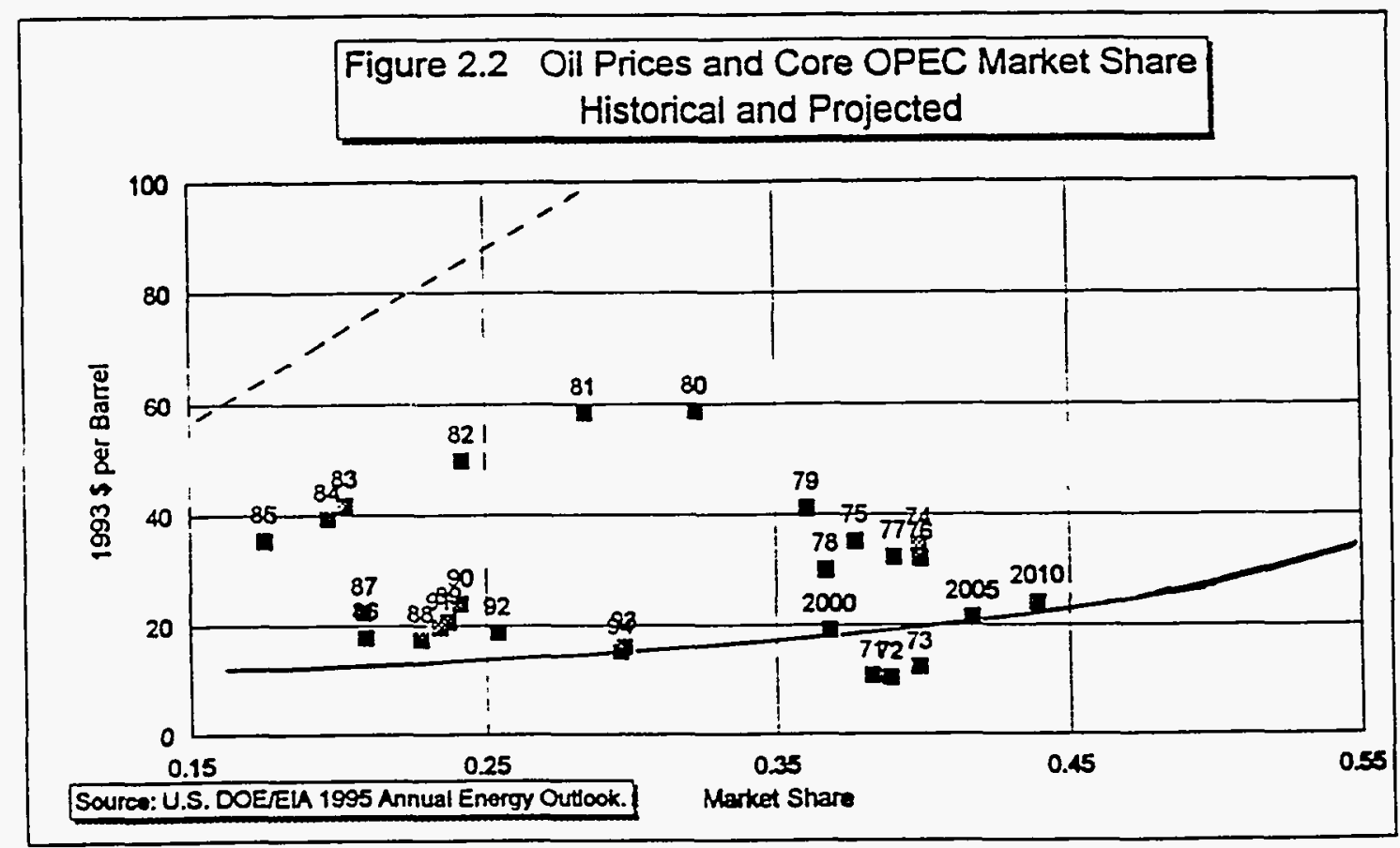

The 1972 and 1973 oil prices appear to fall below even the long-run monopoly price curve, given OPEC's market share. The price shock of the last quarter of 1973 and 1974 raised prices above the long-run curve but well below OPEC's short-run profit-maximizing price. In a growing world market. prices just

'Because short-run elasticities are so small. curves cannot be drawn based on the assumption of constant elasticities. Elasticities must be an increasing (in absolute value) function of oil price. We assume linear supply and demand equations. which satısty this requirement. and the same parameters as Table 1 below. 
above the long-run curve can be maintained indefinitely at a constant market share. This appears to be approximately what was happening from 1974 to 1978. In 1979 and 1980. spurred by the oil supply disruptions due to the Iran-Iraq War. prices rocketed towards short-run profit-maximizing levels. Sustaining these price levels in 1981, 1982. and 1983 cost OPEC dearly in market share. With profits and market share continuing to dwindle in 1984-85. the OPEC resolve cracked. Prices were lowered to approximately the long-run monopoly price level where readjusting economies and economic growth are now building OPEC market share back towards its previous level. Department of Energy forecasts of OPEC market share in 2000. 2005, and 2010 are included to illustrate the expected trends (U.S. DOE/EIA, 1995b).

Studies by Wirl (1990) and Suranovic (1994) have shown that a pricing policy of brief price shocks of two years or so in duration. separated by periods of lower prices may well be a profit maximizing strategy for OPEC. This is bad news for consuming nations since price shocks reduce GNP, tend to increase unemployment and transfer national wealth to oil producing countries.

\section{The Costs of Monopoly Pricing to Oil Consuming Economies}

A sudden increase in the price of oil creates three principal types of economic losses to the U. S. economy:

1. Loss of the potential to produce.

2. Macro-economic adjustment losses. and

3. Transfer of wealth from U. S. oil consumers to foreign oil exporters.

These three effects are separate and additive.

When oil prices rise, they signal the economy that a basic resource has become more scarce. As a result, the economy is able to produce less output with the same resources of capital, labor, materials, and land. The impact of this loss of potential output or GNP, will be greater in the short-run than in the longrun because greater substitution for oil is possible in the long-run. The implications for the economy's longrun potential to produce have been described by Tatom (1993) and many others (e,g, Pindyck, 1980; Burgess, 1984; Pakravan. 1984; etc.). Pindyck (1980, p. 19) estimated a $0.25 \%$ loss of U.S. potential GNP for a $10 \%$ increase in the price of oil, based on "back-of-the-envelope" calculations. and also asserted that the indirect. or macroeconomic adjustment effects would be of roughly equal magnitude. He also noted that the cost of an energy price shock depends on the energy cost share of GNP and that. in the short-run at least, it would be reasonable to assume no substitution possibilities as an approximation. Thus he assumed that the shortrun elasticity of GNP with respect to an energy price shock would equal the negative of the energy cost share of GNP. Tatom (1993. p. 134) also noted the relationship between the impact of oil prices on output and the oil cost share of GNP as well as the fact that the oil cost share today is about what it was in the 1970s.

When prices rise rapidly, additional transitory costs result because wages and prices are not able to adjust sufficiently rapidly to the new oil price regime to permit the economy to operate at full employment. Macroeconomic adjustment losses are in addition to the loss of productive capacity that would occur even were the economy at full employment. Because of stickiness in wages and prices, the economy is unable to immediately adjust to a sudden increase in the price of as important a commodity as oil. These cyclical losses are truly transitory, perhaps lasting only about one year (Tatom. 1993, p. 132). Their effect is to temporarily amplify the loss of output capacity.

Third, when prices are increased by monopoly behavior, there is also a transfer of wealth from U.S. oil consumers to the owners of foreign oil. This "loss" is a transfer payment. It is not a loss of economic output. which distinguishes it from the two economic losses described above. The weaith still exists. ownership is simply transferred from U. S. citizens to foreign oil producers. A similar transfer of wealth also takes place within the U.S. from oil consumers to owners of U.S. oil resources. Since this is internal to the U.S. we do not count it as a loss to the U.S. economy. The transfer of wealth is exactly equal to the quantity of oil the U.S. imports times the difference between the monopoly price and the competitive market price of oil. All three effects have been recognized by economists for some time. 
It is possible to interpret oil dependence costs as being a function of the quantity of oil consumed or the quantity of oil imported by a nation and. therefore. to be similar to external costs. For example, Broadman (1986) and Hogan and Broadman (1988) used the phrase monopsony costs to refer to the fact that a large nation like the U.S.. acting coilectively, has monopsony power as an oil consumer that it could use to counter the monopoly power of the OPEC cartel. The reasoning is as follows: The individual consumer by using an additional barrel of oil causes the world price of oil to rise ever so slightly and the probability of a price shock to increase by a tiny amount. The costs and potential costs are distributed over all oil users in the world: only an infinitesimal fraction is borne by the private individual who consumed the marginal barrel. This looks like an external cost. But is it? I think not. for three reasons. First. there is no necessary connection between the act of consuming an additional barrel of oil and the putative marginal social cost. At any given time, OPEC may or may not choose. or be able to, act as a cartel. Thus, the existence and size of the supposed external cost depends on the behavior of someone else. Second. the size of the external cost depends on the definition of the monopsonist. If one takes Germany to be the monopsonist. the marginal social costs will be much smailer than if one assumes it is the U.S.. or the entire OECD. The bigger the monopsonist the bigger the monopsony power and the greater the implied social cost. Thirdly, if one imposed an "optimal" tax to internalize the supposed external cost. the result would not necessarily be the economically efficient solution. If oil dependence costs are external costs. they are a new kind of external cost. for which we have yet to develop appropriate theory.

\section{Past Costs Have Been Enormous}

The economic costs of past oil dependence have been staggering. Costs to the U.S. economy over the twenty-year period from 1972-1991 have been estimated at \$4 trillion undiscounted 1990 US\$ (Greene and Leiby, 1993). Of that total. wealth transfer comprised $\$ 1.2$ trillion. macroeconomic adjustment costs $\$ 0.8$ trillion, and potential GNP losses $\$ 2.1$ trillion. The methods used are not precise. so that these estimates should be taken as indicative only of the general magnitude of costs. Still, the general magnitude is very large. The entire GNP of the U.S. in 1991 was $\$ 5.5$ trillion. The sum of all U.S. defense expenditures from 1972 to 1991 was $\$ 5.2$ trillion. Total interest payments on the national debt over the same period amounted to a mere \$2.1 trillion. By comparison. the costs of the U.S. primary oil supply contingency program, the Strategic Petroleum Reserve. over the same period were about $\$ 25$ billion or $\$ 15$ billion net. taking into account the value of the oil held (all of the above 1990 US\$).

While there is not space to discuss the details of Greene and Leiby's (1993) methodology here, it relies on an elasticity of GNP with respect to the price of oil of about -0.05 , a value very consistent with econometric analyses and with the results of energy model simulations (Hickman. 1984). They also assume roughly a 50/50 split of GNP impacts between macroeconomic adjustment costs and loss of potential output. They showed, however, that the total cost estimates were not very sensitive to the allocation of the GNP effects. The competitive price of oil was assumed to be a constant $\$ 9 / \mathrm{bbl}$ for the entire period (1990 US\$). Assuming that oil costs would increase at $2 \%$ per year reduces the estimated costs of oil dependence by about $10 \%$.

The majority of the costs are incurred between 1973 and 1985. the year of the first oil price shock and the year prior to the oil price collapse. Between 1973 and 1978, annual costs to the U.S. were about $\$ 200$ billion. Costs peaked at over $\$ 400$ billion in 1980 and fell sharply each year afterwards through 1986 . Since then total oil dependence costs have been about $\$ 50$ billion annually, comprised mainly of wealth transfer and potential output loss. Today, oil dependence is generally not perceived to be a problem in the U.S. Oil prices are low, supplies are abundant. Is the oil problem over? 


\section{The Oil Problem Has Not Gone Away}

Since 1973. the basic determinants of U.S. vulnerability to monopoly behavior in worid oil markets have changed less than one might think: 1) OPEC's market share has fallen but is on the rise: 2) oil demand. now more concentrated than ever in the transport sector. remains price inelastic: 3 ) the oil cost-share of GNP is about what it was before the first oil price shock: and 4) the level of U.S. imports. key determinant of the transfer of U.S. wealth. is as high as ever. OPEC's monopoly power depends on its share of low-cost worid oil resources and its correspondingly large share of the world oil market. as well as from the inelasticity of short- and long-run world oil supnly and demand. Market share OPEC lost defending high prices from 198085 is being rapidly regained. It appears that reports of OPEC's demise have, to paraphrase Mark Twain, been greatly exaggerated. Lost market share can and is being regained. and with it comes market power. The Energy Information Administration (U. S. DOE/EIA, 1995b) projects that by 2005. OPEC's market share is likely to exceed the levels of the 1970s (Figure 5.1).

Figure 5.1

\section{OPEC Share of World Oil Market}

Historical to 1993 and Projected to 2010

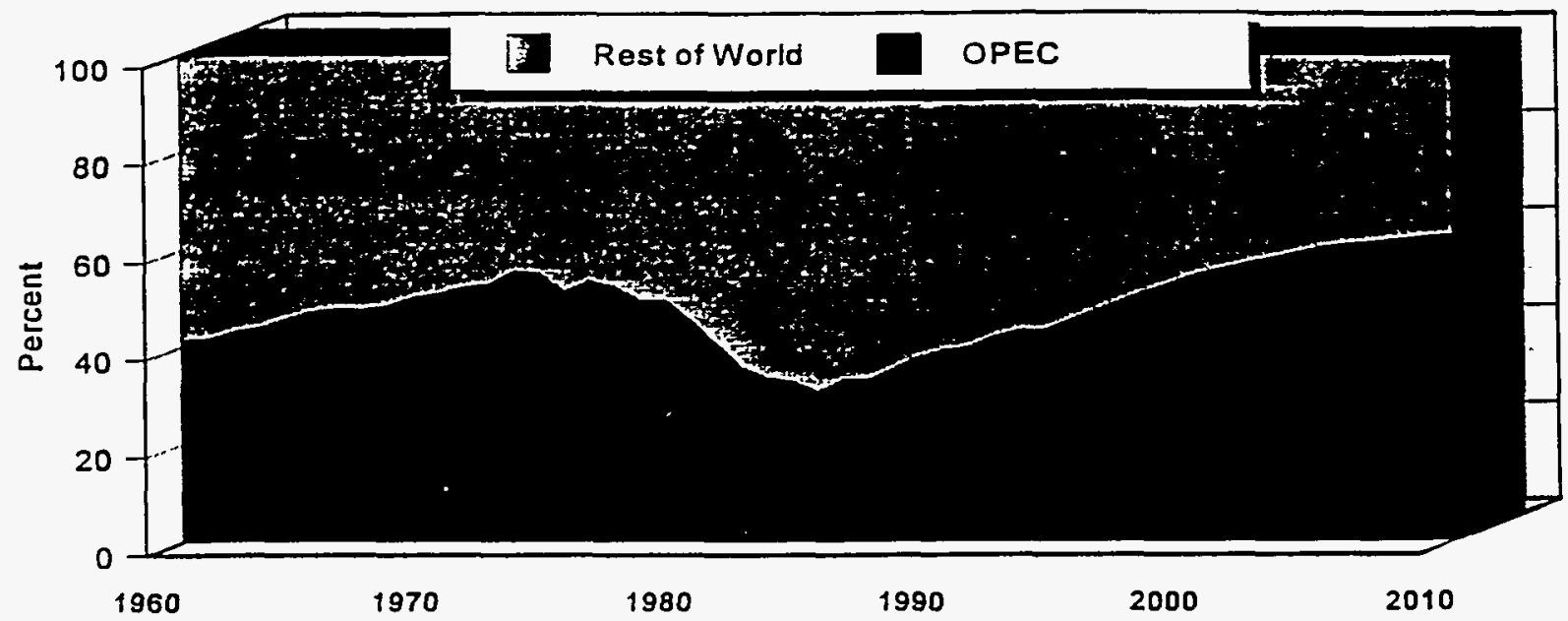

Source: U. S. DOE/EIA, 1995b, Table C.20, 1994a. Table 11.5

Though the economy`s dependence on energy and oil since 1981 has been significantly reduced. it is now about the same as it was at the time of the first oil price shock. In 1973 the net cost of oil to the U. S. amounted to $1.5 \%$ of GDP. In 1992 oil's cost share was $1.5 \%$, and decreased to $1.3 \%$ in 1993 . To be sure, oil costs rose during the late 1970 s and early 1980 s with the price of oil. They will rise again with future oil price hikes. The important point is that oil's importance to the U.S. economy is about the same as it was twenty years ago, before the Arab OPEC oil embargo of 1973-74. The uses of oil have changed somewhat. increasing the importance of transportation oil use as other sectors moved away from oil.

The transfer of wealth from U.S. consumers to foreign owners of oil depends directly on the level of U.S. imports. Current levels of U.S. oil imports are higher than those preceding the first oil price shock in 1973-74 and almost equal to the highest level on record: $46.5 \%$ in 1977 . U. S. oil imports have been rising since 1982 and are expected to continue to rise in the future. The EIA predicts that U. S. imports will increase from their current level of $45 \%$ of U. S. consumption into the range of $58 \%$ to $67 \%$ by 2000 , and 
from $58 \%$ to $77 \%$ by 2010 . A given OPEC price hike in the future will almost surely cause a greater loss of U.S. wealth than in the past because the U.S. will be importing more oil.

Finally, some argue that oil futures markets significantly reduce or even eliminate the costs of monopoly vil pricing and price shocks to the U.S. This is absurd. The purpose of futures markets is to allow oil consumers to hedge, in effect buy insurance. against the private costs of future price increases. The option to hedge was not created by futures markets. they merely reduce the transaction costs of hedging. As private markets. futures markets cannot internalize the societal costs of oil dependence due to monopoly behavior by OPEC.

\section{Future Costs of Oil Dependence}

Future oil price shocks have been simulated by the U.S. Department of Energy (U.S. DOE/EIA, 1994d), Suranovic (1994), and Greene. Leiby and Jones (1995). All confirm that future oil markets are likely to be as susceptible as in the past to price shocks due to relatively minor supply curtailments. The U.S. DOE's projection indicated that a 5.25 MMBD net supply reduction in the year 2000 would cause oil prices to surge to $\$ 55 / \mathrm{bbl}(1993 \$)$. Suranovic (1994) estimated much higher price increases for considerably larger supply reductions. Greene. et al. (1995) predicted that a 10\% reduction in OPEC supply in 2005 (5.5 MMBD) would cause the world oil price to jump to $\$ 54 / \mathrm{bbl}$. If these simulations are approximately correct. future oil dependence will be much the same as the past.

The costs of future oil dependence are also likely to be huge. Greene. Leiby, and Jones estimated the impacts on the U.S. economy of a two-year supply shock. followed by a period of OPEC supply restraint. They found that this single event would cost the U.S. economy an additional half trillion dollars. Starting from the U.S. DOE 1994 Reference Case forecast. a supply disruption of 5.5 MMBD is assumed to occur in 2005 , as a result of a $10 \%$ reduction in OPEC output over 2004. Consequently, oil prices are estimated to increase from $\$ 21 / \mathrm{bbl}$ to $\$ 54 / \mathrm{bbl}$. To keep prices elevated, it is assumed that OPEC further reduces production in 2006 to a total of $17 \%$ less than in 2004 . Despite this, the price of oil declines to $\$ 46 / \mathrm{bbl}$ as the world economy adjusts. Thereafter, OPEC is assumed to increase production by only about $2-3 \%$ per year. stabilizing prices at $\$ 28-\$ 30 / \mathrm{bbl}$ through 2010 . Greene. et al. estimate that this strategy boosts OPEC revenues by more than half a trillion dollars over what they would have received during the 2005 to 2010 period (all costs and revenues presented are in 1993 US \$. discounted to present value at 4\%/yr.).

The price shock and supply restraint scenario costs the U.S. an additional \$0.5 trillion over the Reference Case costs. This is distributed between $\$ 0.14$ trillion wealth transfer. $\$ 0.26$ trillion potential GNP loss and \$0.14 trillion macroeconomic adjustment costs (all 1993 US\$, PV). Not deflated to present value, U.S. oil dependence costs peak at $\$ 550$ billion in 2005 but by 2007 drop back to $\$ 150$ billion annually (Figure 6.1).

\section{What Can Be Done?}

It is reasonable to ask what can be done to avoid the costs of oil dependence? If the costs are unavoidable. there is nothing to be gained by worrying about them. Suranovic (1994) estimated the impacts of tariffs and use of the U.S. Strategic Petroleum Reserve as strategies against future oil prices shocks and found them to be only modestly effective. In the case of an oil import tariff. he found that a $70 \%$ tariff by the U.S. alone would reduce oil price spikes by about $25 \%$. If the OECD applied such a tariff price spikes would be reduced by $30 \%$. While Suranovic did not estimate the economic costs to the U.S.. it is clear that the benefit of lower price spikes would be offset to some degree by the higher price of oil during undisrupted periods. Suranovic also explored the effectiveness of strategic reserves against a determined policy of OPEC revenue maximization through price shocks. He found that to maintain an effective strategy through 2010 would 
Figure 6.1 Costs of Oll Dependence to U.S.

Economy: Price Shock Scenario

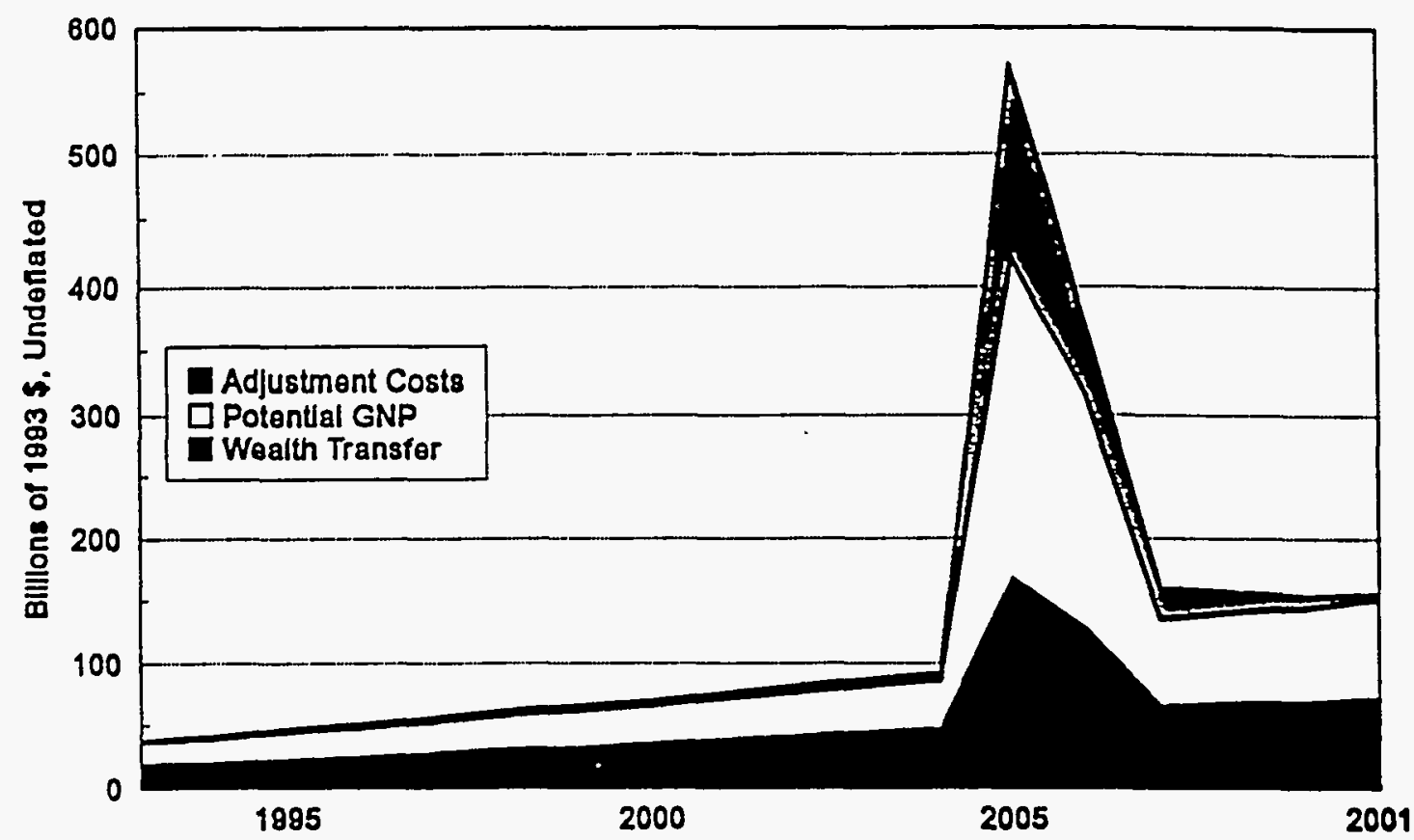

require as much as a 50 billion barrel reserve. far more than the 3.5 billion barrels of total reserves currently held in OECD countries and 50 times current OECD strategic reserves.

These results for strategic reserves were confirmed by Greene. Leiby and Jones (1995), who found that maximum use of the 0.6 billion barrel U.S. strategic reserve in the first year of the simulated supply cutback reduced total OPEC revenues by only $5 \%$ through 2010. Similarly, the economic impacts of the price shocks on the U.S. economy were reduced by only $2 \%$ by use of the strategic reserve. The reason is that use of the reserve delays adjustment of supply and demand. thus magnifying the supply reductions in succeeding years. With use of the U.S. strategic reserve. the estimated oil price is $\$ 10$ lower in 2005 but $9 \$$ higher in 2006. While the precision of these numbers may be questioned. the basic result seems sound. strategic reserves must be enormous to have a profound impact on determined monopolistic behavior by the OPEC cartel or to safeguard economies against its consequences. Even doubling the U.S. reserves and releasing them over two years only approximately doubled their relatively minor impact.

If tariffs and reserves appear to be relatively ineffectual weapons, what can work? Greene, et al. (1995) explored the impacts of doubling U.S. and world price elasticities of oil supply and demand. They assumed that elasticities would begin increasing in 1996 and be doubled by 2005 . Price elasticities can be changed either by changing preferences or by changing the technology of energy use. Doubling elasticities would surely require major changes in transportation technology, since it is the transportation sector that dominates oil demand. Doubling world price elasticities could have a dramatic effect. Assuming the same pattern of OPEC production, costs to the U.S. economy in the price shock scenario with doubled elasticities would be \$0.9 trillion less: $\$ 0.6$ versus $\$ 1.5$ trillion (1993 US\$. PV). Even if only the U.S. doubled its elasticities, oil dependence costs would drop by $\$ 0.6$ trillion. Interestingly, if OPEC reacted to the increased world elasticities by aggressively seeking to maintain the revenues it enjoyed in the Reference Case with original elasticities. it would have to cut production so much by 2005 that it would be unable to stage a major price shock in that year. The result. in fact. would be highly counterproductive: instead of receiving $\$ 1.1$ trillion (Reference Case production. doubled world elasticities), the aggressive path would produce only $\$ 0.8$ trillion in revenue through 2010. Moreover. OPEC market share would be so diminished that future revenues would suffer. as well. so that the true loss is much understated. Doubling price elasticities essentially halves OPEC 
revenues and cuts oil dependence costs by up to two-thirds. The answer seems clear: to reduce the costs of oil dependence we must transform the technology of transportation energy use and supply.

\section{References}

Broadman. H. G. (1986). “The Social Cost of Imported Oil," Energy Policy, vol. 14, no. 3. pp. 242-252, June.

Gordon, R. L. (1994). "Energy, Exhaustion. Environmentalism. and Etatism.” The Energy Journal, vol. 15, no. 1 , pp. 1-16.

Greene, D. L. (1991). “A Note on OPEC Market Power and Oil Prices," Energy Economics, vol. 13, no. 2, pp. 123-129.

Greene, D. L. and P. N. Leiby. (1993). "The Social Costs to the U. S. of Monopolization of the World Oil Market. 1972-1991." ORNL-6744. Oak Ridge National Laboratory, Oak Ridge. Tennessee, March.

Greene, D.L., P.N. Leiby, and D.W. Jones. (1995). “The Outlook for U.S. Oil Dependence”. ORNL-6673, Oak Ridge National Laboratory, Oak Ridge. Tennessee. May.

Hall. D. C. (1992). "Oil and National Security." Energy Policy. November. pp. 1089-1096.

Hickman. B. G. (1987). "Macroeconomic Impacts of Energy Price Shocks and Policy Responses: A Structural Comparison of Fourteen Models." in Macroeconomic Impacts of Energy Shocks, B. G. Hickman, H. G. Huntington. and J. L. Sweeney, eds., Elsevier Science Publishers. B.V., North Holland.

Hogan, W. W. and H. G. Broadman. (1988). "Oil Tariff Policy: An Overview," Energy Systems and Policy, vol. 12, pp. 63-68.

MacFadyen, A. J. (1993). "OPEC and Cheating: Revisiting the Kinked Demand Curve," Energy Policy, vol. 21 , no. 8 , pp. 858-867.

Masters, C. D., E. D. Attanasi and D. H. Root. (1994). "World Petroleum Assessment and Analysis," U. S. Geological Survey, National Center. Reston. Virginia.

Pindyck, R. S. (1980). "Energy Price Increases and Macroeconomic Policy," The Energy Journal, vol. 1, no. 4, pp. 1-20.

Suranovic. S. M. (1994). "Import Policy Effects on the Optimal Oil Price." The Energy Journal. vol. 15, no. 3, pp. 123-144.

Tatom. John A. (1993). “Are There Useful Lessons from the 1990-91 Oil Price Shock?” The Energy Journal. vol. 14, no. 4. pp. 129-150.

U. S. Department of Energy, Energy Information Administration. (1994c). International Energy Annual 1992, DOE/EIA-0219(92), Washington. DC.

U. S. Department of Energy, Energy Information Administration. (1994d). International Energy Outlook 1994, DOE/EIA-0484(94), Washington. DC.

U. S. Department of Energy, Energy Information Administration. (1995b). Annual Energy Outlook 1995, DOE/EIA-0383(95), Washington. DC.. January.

Wirl. F. (1990). "Dynamic Demand and Optimal OPEC Pricing," Energy Economics, vol. 12. no. 3, pp. 174-177. 